\title{
Karakteristik Sifat Fisik Dan Organoleptik Sirup Asam (Tamarindus Indica Linn.) Pada Berbagai Konsentrasi Gula
}

\author{
Febrina Sulistiawati \\ Universitas Nahdlatul Ulama Nusa Tenggara Barat \\ Email : $\underline{\text { r_febri@yahoo.co.id }}$
}

\begin{abstract}
Abstrak : Pada penelitian ini dilakukan pengujian karakteristik sifat fisik berupa nilai $\mathrm{pH}$ dan viskositas serta sifat organoleptik berupa rasa dan warna pada sirup asam (Tamarindus indica Linn.) yang ditambahkan enam perlakuan konsentrasi gula. Penelitian ini bertujuan untuk mendapatkan konsentrasi gula yang tepat dalam menghasilkan sirup asam dengan kualitas terbaik dan diharapkan dapat memperbanyak variasi produk olahan yang dihasilkan dari buah asam. Metode yang digunakan dalam penelitian ini adalah metode eksperimental. Rancangan yang digunakan adalah Rancangan Acak Lengkap (RAL) dengan faktor tunggal konsentrasi gula menggunakan enam perlakuan dengan tiga kali ulangan sehingga dihasilkan 18 unit percobaan. Hasil pengamatan selanjutnya dianalisis menggunakan analisis keragaman (ANOVA) pada taraf nyata 5\%, bila terdapat beda nyata maka diuji lanjut menggunakan Uji Beda Nyata Jujur (BNJ) pada taraf nyata yang sama. Hasil penelitian menunjukkan bahwa penambahan berbagai konsentrasi gula memberikan pengaruh yang nyata terhadap nilai $\mathrm{pH}$, viskositas, rasa dan warna. Dari penelitian ini dapat disimpulkan bahwa semakin tinggi penambahan konsentrasi gula maka semakin tinggi pula nilai $\mathrm{pH}$ dan viskositas. Dan berdasarkan hasil uji organoleptik, sirup asam yang lebih disukai oleh panelis adalah sirup dengan penambahan konsentrasi gula 160 dan $180 \%$ dengan warna coklat.
\end{abstract}

Kata kunci : sifat fisik, organoleptik, sirup asam

\section{PENDAHULUAN}

Tanaman asam (Tamarindus indica Linn.) merupakan salah satu tanaman tropis yang berbuah polong. Di Indonesia, buah asam belum mendapat perhatian khusus karena nilai ekonominya yang rendah. Pada umumnya, pohon asam hanya tumbuh sebagai perindang atau peneduh jalan-jalan besar. Padahal, bila diolah dengan teknologi yang tepat nilai ekonomi buah asam dapat lebih ditingkatkan. Awalnya, buah asam hanya digunakan sebagai bumbu penyegar sayuran dan bahan obat-obatan tradisional. Seiring dengan perkembangan industri pengolahan hasil pertanian, buah asam kini telah diolah menjadi kembang gula, sirup, dan bahan minuman.

Tamarindus indica Linn. mengandung berbagai kandungan isi, seperti senyawa fenol, glikosida, mallic acid, tartaric acid, getah, pektin, arabinosa, xylosa, galaktosa, glukosa, uronic acid, asam lemak, serta berbagai elemen esensial seperti arsenik, calcium, cadmium, tembaga, besi, sodium, mangan, magnesium, potassium, fosfor, zinc dan sedikit vitamin A. Penelitian yang telah berkembang menunjukkan bahwa tanaman ini berperan sebagai antioksidan yang kuat, mempunyai aktifitas anti inflamasi, anti alergi, analgesik, dapat menurunkan kadar gula darah, mempunyai aktifitas sebagai antibiotik, dapat mempengaruhi motilitas usus, juga berperan dalam menghambat pertumbuhan kanker (Putri, 2014).

Melihat beragamnya manfaat tanaman asam bagi kesehatan, maka buah ini perlu ditingkatkan nilai ekonominya. Buah asam dapat diolah menjadi berbagai produk olahan. Buah asam yang masih muda dapat diolah menjadi manisan basah, manisan kering, pickle, jam dan jelly, sedangkan buah asam yang masak dapat diolah menjadi nata, tepung ataupun sirup.

Sirup adalah sejenis minuman berupa larutan yang kental dengan citarasa beraneka ragam. Sirup buah adalah sirup yang dibuat dari bahan baku buah-buahan. Berbeda 
dengan sari buah, penggunaan sirup tidak langsung diminum tapi harus diencerkan terlebih dahulu. Pengenceran dilakukan karena kadar gula dalam sirup yang terlalu tinggi (Satuhu, 2004 dalam Fitri dkk., 2017). Berdasarkan uraian di atas, maka dilakukan penelitian mengenai pengujian karakteristik sifat fisik ( $\mathrm{pH}$ dan viskositas) serta organoleptik (rasa dan warna) sirup asam pada berbagai konsentrasi gula.

\section{METODE PENELITIAN}

\section{Bahan}

Bahan-bahan yang digunakan dalam penelitian ini adalah buah asam, gula pasir, natrium benzoate, CMC dan aquades.

\section{Alat}

Adapun alat-alat yang digunakan dalam penelitian ini adalah timbangan, botol, baskom, kompor, panci, piring, stopwatch, $\mathrm{pH}$ meter, viskometer, panelis dan alat tulis menulis.

\section{Pelaksanaan Penelitian}

Buah yang digunakan adalah buah asam varietas asam jawa yang telah masak sempurna di pohon. Daging buah dipisahkan dari biji dan serat lalu dikukus menggunakan uap panas selama 25 menit. Pengukusan ini bertujuan untuk menginaktifkan enzim dan melunakkan jaringan daging buah asam sehingga mudah untuk dijadikan bubur. Selanjutnya daging buah diekstraksi dengan menambahkan air panas dengan perbandingan 1:3 (1 bagian asam : 3 bagian air panas). Tahap berikutnya adalah penyaringan menggunakan kain kasa untuk mendapatkan ekstrak yang bersih. Penyaringan dilakukan sebanyak dua kali agar didapatkan ektrak yang benar-benar bersih dan jernih. Ekstrak kemudian ditimbang beratnya selanjutnya dicampur gula pasir dengan konsentrasi 100, 120, 140, 160, 180 dan $200 \%$ dari berat ekstrak. Selain itu ditambahkan pula natrium benzoat sebagai pengawet sebanyak $600 \mathrm{ppm}$ dan CMC sebagai penstabil dengan kadar $0,15 \%$. Setelah itu dilakukan pemasakan pada suhu $80-100^{\circ} \mathrm{C}$ selama 10 menit dengan tujuan untuk melarutkan gula pasir, natrium benzoat dan CMC serta menginaktifkan sel-sel vegetatif bakteri dan mikroba patogen atau pembusuk yang dapat menyebabkan kerusakan pada produk setelah penyimpanan. Parameter Pengamatan

Tingkat keasaman $(\mathrm{pH})$. Pengukuran $\mathrm{pH}$ dilakukan menggunakan $\mathrm{pH}$ meter dengan prosedur sebagai berikut : Sirup asam sebanyak 20 gram dimasukkan ke dalam gelas piala lalu ditambahkan aquades. $\mathrm{pH}$ meter dikalibrasi dengan larutan buffer, kemudian sirup asam diaduk dengan magnetic stirrer. Selanjutnya, elektroda $\mathrm{pH}$ meter dimasukkan ke dalam sirup yang diaduk. $\mathrm{pH}$ sirup terlihat pada monitor $\mathrm{pH}$ meter.

Tingkat kekentalan (viskositas). Kekentalan diukur menggunakan capillary viscometer (Sukardjo, 1997) dengan prosedur sebagai berikut : Pipa B pada viskometer ditutup lalu dimasukkan sirup asam ke dalam viskometer melalui pipa A dan dibiarkan sampai tanda batas awal K1. Pipa B selanjutnya dibuka dan sirup asam dibiarkan mengalir dari awal tanda batas K1 ke akhir tanda batas K1. Dihitung waktu yang dibutuhkan untuk aliran tersebut dengan stopwatch.

$\underline{\text { Rasa. }}$ Penentuan rasa dilakukan secara organoleptik dengan uji hedonic scale. Sirup asam disajikan secara acak kepada 15 panelis dengan kode tiga angka digit. Panelis diminta untuk memberikan penilaian sesuai dengan tingkat kesukaan terhadap rasa sesuai dengan kriteria yang ditentukan. Hasil dari uji hedonic scale dinyatakan dengan angka yang menunjukkan tingkat kesukaan panelis sebagai berikut :

$1=$ sangat tidak suka

2 = tidak suka

$3=$ agak tidak suka

$4=$ netral/biasa

$5=$ agak suka

$6=$ suka

7 = sangat suka

Warna. Penentuan warna dilakukan secara organoleptik dengan uji scoring. Sirup asam disajikan secara acak kepada 15 panelis dengan kode tiga angka digit. Panelis diminta untuk memberikan penilaian terhadap warna sesuai dengan kriteria yang ditentukan. Hasil dari uji scoring dinyatakan dengan angka 
yang menunjukkan tingkat kesukaan panelis sebagai berikut :

$1=$ coklat kekuningan

2 = coklat muda

$3=$ coklat

$4=$ coklat tua

$5=$ coklat kehitaman

\section{Analisis Data}

Penelitian ini menggunakan Rancangan Acak Lengkap (RAL) dengan faktor tunggal konsentrasi gula $(\mathrm{g})$ dengan perlakuan sebagai berikut :

g1 : konsentrasi gula $100 \%$

g2 : konsentrasi gula $120 \%$

g3 : konsentrasi gula $140 \%$

g4 : konsentrasi gula $160 \%$

g5 : konsentrasi gula $180 \%$

g6 : konsentrasi gula $200 \%$

Setiap perlakuan dibuat tiga kali ulangan sehingga dihasilkan 18 unit percobaan. Data hasil pengamatan dianalisa menggunakan analisa keragaman (ANOVA) pada taraf nyata $5 \%$. Bila terdapat beda nyata maka diuji lanjut menggunakan Uji Beda Nyata Jujur (BNJ) pada taraf nyata yang sama.

\section{HASIL DAN PEMBAHASAN}

Berdasarkan analisis data yang dilakukan, diperoleh hasil bahwa perlakuan penambahan konsentrasi gula memberikan pengaruh yang berbeda nyata terhadap parameter sifat fisik ( $\mathrm{pH}$ dan viskositas) serta organoleptik (rasa dan warna). Hasil uji lanjut dapat dilihat pada tabel berikut :

Tabel 1. Hasil Uji Lanjut Parameter Sifat Fisik ( $\mathrm{pH}$ dan Viskositas)

\begin{tabular}{|c|c|c|}
\hline Konsentrasi Gula (\%) & $\mathrm{pH}$ & Viskositas \\
\hline 100 & $2.463 \mathrm{a}$ & $0.030 \mathrm{a}$ \\
120 & $2.533 \mathrm{~b}$ & $0.032 \mathrm{a}$ \\
140 & $2.550 \mathrm{bc}$ & $0.042 \mathrm{ab}$ \\
160 & $2.563 \mathrm{bc}$ & $0.058 \mathrm{ab}$ \\
180 & $2.590 \mathrm{bc}$ & $0.078 \mathrm{bc}$ \\
200 & $2.600 \mathrm{c}$ & $0.108 \mathrm{c}$ \\
\hline BNJ $5 \%$ & 0.061 & 0.039 \\
\hline
\end{tabular}

Keterangan : Angka-angka yang diikuti oleh huruf yang sama menunjukkan tidak berbeda nyata pada taraf $5 \%$

\section{Pengaruh Konsentrasi Gula Terhadap pH Sirup Asam \\ Berdasarkan Tabel 1 dapat dilihat bahwa nilai $\mathrm{pH}$ sirup asam semakin}

meningkat dengan meningkatnya penambahan konsentrasi gula. Meningkatnya nilai $\mathrm{pH}$ sirup asam disebabkan oleh lebih tingginya $\mathrm{pH}$ gula daripada $\mathrm{pH}$ asam. Menurut Khalid dan Zakaria (1985), $\mathrm{pH}$ asam masak sekitar 2,4; sedangkan Goutara dan Wijandi (1975) dalam Susantriana (2000) menyatakan bahwa $\mathrm{pH}$ sukrosa sekitar 6,3-6,4; dan penambahan sukrosa pada bahan pangan dapat meningkatkan $\mathrm{pH}$ bahan pangan tersebut. Hal ini sesuai pula dengan hasil penelitian Gianti dan Evanuarini (2011) yang menyatakan bahwa semakin tinggi penambahan gula maka semakin meningkat pula $\mathrm{pH}$ susu fermentasi. Demikian pula hasil penelitian Silfia dan Agustini (2014) pada vinegar dari air kelapa yang menyatakan bahwa kadar asam asetat vinegar meningkat dengan adanya penambahan gula.

\section{Pengaruh Konsentrasi Gula Terhadap Viskositas Sirup Asam}

Hasil penelitian menunjukkan bahwa nilai viskositas sirup asam semakin meningkat dengan meningkatnya penambahan konsentrasi gula (Tabel 1). Meningkatnya viskositas sirup asam disebabkan oleh semakin banyaknya gula yang berdifusi ke dalam molekul-molekul air dan memenuhi rongga-rongga dinding sel bahan sehingga bahan menjadi lebih kental. Hal ini sejalan dengan hasil penelitian Gianti dan Evanuarini (2011) dimana semakin tinggi penambahan gula maka semakin meningkat pula viskositas susu fermentasi akibat berkurangnya aktifitas air. Pada penambahan konsentrasi gula 200\% didapatkan sirup asam dengan viskositas yang lebih tinggi dengan penambahan konsentrasi gula lainnya, hal ini terjadi karena tingginya tekanan osmosis yang dihasilkan sehingga semakin banyak gula yang berdifusi ke dalam molekul-molekul air dan menyebabkan bahan menjadi lebih kental.

Sementara itu, hasil uji lanjut pada parameter organoleptik (rasa dan warna) sirup asam dapat dilihat pada tabel berikut :

Tabel 2. Hasil Uji Lanjut Parameter Organoleptik (Rasa dan Warna) 


\begin{tabular}{|c|l|l|}
\hline Konsentrasi Gula $(\%)$ & Rasa & Wama \\
\hline 100 & $3.933 \mathrm{a}$ & $1.467 \mathrm{a}$ \\
120 & $5.200 \mathrm{~b}$ & $1.800 \mathrm{a}$ \\
140 & $5.533 \mathrm{~b}$ & $1.867 \mathrm{a}$ \\
160 & $5.533 \mathrm{~b}$ & $2.667 \mathrm{~b}$ \\
180 & $6.067 \mathrm{~b}$ & $2.733 \mathrm{~b}$ \\
200 & $5.067 \mathrm{ab}$ & $4.000 \mathrm{c}$ \\
\hline BNJ 5\% & 1.144 & 0.643 \\
\hline
\end{tabular}

Keterangan : Angka-angka yang diikuti oleh huruf yang sama menunjukkan tidak berbeda nyata pada taraf $5 \%$

\section{Pengaruh Konsentrasi Gula Terhadap Rasa Sirup Asam}

Pada Tabel 2 dapat dilihat bahwa respon panelis pada perlakuan konsentrasi gula terendah (100\%) adalah netral/biasa. Respon panelis mulai meningkat menjadi suka pada konsentrasi gula 120 hingga $180 \%$, kemudian pada konsentrasi gula tertinggi (200\%) respon panelis menurun menjadi agak suka. Meningkatnya kesukaan panelis pada konsentrasi gula 120 hingga 180\% disebabkan oleh penambahan gula yang semakin meningkat sehingga memberikan tambahan citarasa pada sirup asam. Hal ini sesuai dengan pendapat Buckle dkk (2007) yang menyatakan bahwa gula dalam makanan dan minuman memiliki pengaruh menambah citarasa pada makanan dan minuman tersebut. Hal ini sejalan dengan penelitian Octaviani dan Rahayuni (2014) dimana semakin tinggi penambahan gula, rasa sari buah buni makin disukai.

Sementara itu, menurunnya tingkat kesukaan panelis pada konsentrasi gula tertinggi (200\%) diduga disebabkan oleh mulai jenuhnya panelis terhadap rasa sirup yang terlalu manis. Winarno (2002) menyatakan bahwa kekentalan atau viskositas suatu bahan mempengaruhi citarasa yang ditimbulkan oleh bahan tersebut, semakin kental suatu bahan maka penerimaan terhadap intensitas citarasa bahan tersebut semakin berkurang. Pada konsentrasi gula 200\%, sirup asam yang didapatkan sangat kental sehingga inilah yang menyebabkan menurunnya penerimaan panelis.

Pengaruh Konsentrasi Gula Terhadap Warna Sirup Asam

Hasil penelitian menunjukkan bahwa pada perlakuan konsentrasi gula 100, 120 dan
140\% warna sirup asam yang diamati oleh panelis adalah coklat muda, pada konsentrasi gula 160 dan $180 \%$ warna sirup asam meningkat menjadi coklat dan pada konsentrasi gula tertinggi (200\%) warna sirup asam berubah menjadi coklat tua (Tabel 2). Perubahan warna sirup asam pada penambahan berbagai konsentrasi gula ini disebabkan oleh terjadinya reaksi pencoklatan non enzimatis pada saat proses pemanasan berlangsung. Reaksi pencoklatan non enzimatis yang merupakan reaksi Maillard ini terjadi karena bereaksinya gula pereduksi dengan gugus amina pada bahan sehingga menyebabkan bahan berwarna coklat (Winarno, 2002).

Berdasarkan data hasil pengamatan dapat dilihat bahwa perubahan tingkat warna sejalan dengan peningkatan penambahan konsentrasi gula pada sirup asam. Hal ini karena pada kandungan gula yang tinggi laju pencoklatan pada bahan pangan yang dipanaskan dapat lebih tinggi sehingga terjadinya reaksi pencoklatan yang menyebabkan perubahan warna bahan berlangsung dengan sangat mudah. Hal inilah yang menyebabkan warna sirup asam dengan penambahan konsentrasi gula tertinggi (200\%) memiliki warna yang lebih coklat (coklat tua) dibandingkan dengan warna sirup asam dengan penambahan konsentrasi gula yang lebih rendah.

\section{KESIMPULAN}

Berdasarkan hasil pengamatan dan hasil analisis serta pembahasan yang terbatas pada ruang lingkup penelitian maka diambil kesimpulan :

1. Penambahan berbagai konsentrasi gula memberikan pengaruh yang berbeda nyata terhadap sifat fisik ( $\mathrm{pH}$ dan viskositas) serta organoleptik (rasa dan warna) sirup asam.

2. Semakin tinggi konsentrasi gula yang ditambahkan maka semakin tinggi pula nilai $\mathrm{pH}$ dan viskositas.

3. Penambahan konsentrasi gula menyebabkan semakin coklatnya warna sirup asam; dan sirup yang lebih disukai panelis adalah sirup dengan penambahan konsentrasi gula 160 dan $180 \%$. 
DAFTAR PUSTAKA Buckle, K.A., R.A. Edward, G.H. Fleet dan M. Wootton. 2007. Ilmu Pangan. Universitas Indonesia Press. Jakarta.

Fitri, E., N. Harun, V.S. Johan. 2017. Konsentrasi Gula dan Sari Buah Terhadap Kualitas Sirup Belimbing Wuluh (Averrhoa bilimbi L.). JOM Faperta UR Vol. 4(1) : 1-13.

Khalid N.M., R. Zakaria. 1985. New Products from Under Utilized Malaysian Fruits For The Local Food Industry. Proceedings of Workshop on Food Technology Research and Development. Bangkok.

Sukardjo. 1997. Kimia Fisika. Rineka Cipta. Jakarta.

Susantriana, B. 2000. Pengaruh Konsentrasi Gula Terhadap Beberapa Sifat Fisik dan Kimia Leather Buah Jambu Mete (Anacardium occidentale L.). Skripsi. Fakultas Pertanian Universitas Mataram. Mataram

Gianti I, H. Evanuarini. 2011. Pengaruh Penambahan Gula dan Lama Penyimpanan Terhadap Kualitas Fisik Susu Fermentasi. Jurnal Ilmu dan Teknologi Hasil Ternak Vol. 6(1) : 2833.

Octaviani L.F., A. Rahayuni. 2014. Pengaruh Berbagai Konsentrasi Gula Terhadap Aktivitas Antioksidan dan Tingkat Penerimaan Sari Buah Buni (Antidesma bunius). Journal of Nutrition College Vol. 3(4) : 958-965.

Putri, C.R.H. 2014. Potensi dan Pemanfaatan Tamarindus indica Dalam Berbagai Terapi. Jurnal Ilmiah Kedokteran Vol. 3(2) : 40-54.

Silfia, S. Agustini. 2014. Pengaruh Penambahan Gula Terhadap Kualitas Vinegar dari Air Kelapa. Jurnal Dinamika Penelitian Industri Vol. 25(2) : 117-124.

Winarno, F.G. 2002. Kimia Pangan dan Gizi. PT Gramedia Pustaka Utama. Jakarta. 